\title{
Social and Normative Meanings in Lexis of Semantic and Motivational Field "Labour"
}

\section{[Социально-нормативные смыслы в лексике семантико- мотивационного поля «Труд»]}

\author{
Tatyana Leontyeva
}

\section{DOI: 10.18355/XL.2015.08.03.19-30}

\begin{abstract}
Аннотация
В статье изложены результаты исследования социально-нормативной семантики в лексическом поле «Труд». Характеризуются способы ее репрезентации. Автор полагает, что в одних случаях социально-нормативные смыслы включены в денотацию слов, в других - присутствуют в виде прагматических коннотаций слова или фразеологизма. Материалом анализа выступили номинации, принадлежащие русским народным говорам. Уделяется внимание словам, запечатлевшим социальную природу коллективного труда, а также оценочным характеристикам человека по трудовым качествам.
\end{abstract}

Ключевые слова

русские народные говоры; социально-нормативный компонент семантики; характеристики человека по трудовым качествам

\section{Введение}

В состав лексико-семантического поля «Труд» могут быть включены обозначения самых разных объектов: орудий труда, трудовых отношений, разных видов работ, профессий, трудовых функций, характеристик труда, человека по его отношению к труду, умению или неумению работать и т. д. Этому полю или отдельным его сегментам посвящено немало работ, в которых слова и фразеологические единицы данной сферы рассматриваются с позиций семасиологического или ономасиологического подходов (Borsheva, 2012; Brysina, 2001; Eremina, 2003; Kruglykova, 1992; Litvinova, 2011; Markelova, 2004; Suslovich, 2010; Tokarev, 2003; Yanyshkova, 2008 и мн. др.).

Лишь часть этих номинаций фиксирует социально значимые смыслы, то есть такие, которые свидетельствуют о концептуализации труда как социального феномена, необходимого для организации жизни человеческого сообщества (трудовая деятельность обеспечивает существование людей и потому целенаправленно организуется ими, при этом разным историческим типам обществ соответствуют разные формы организации труда) и обусловливающего связи между людьми (во-первых, мнение о человеке складывается на основе оценки его качеств, среди которых не последнее место занимают трудовые качества; во-вторых, некоторые виды работ предполагают совместный труд, в том числе коллективную работу целой общины). Комментируя номинации этой сферы, авторы обращают внимание на случаи актуализации связи между понятиями «труд» и «социум», «труд» и «норма», однако последовательное выявление в лексике поля «Труд» комплекса соционормативных сем еще лежит в области нерешенных лингвистических задач. Далее будет представлен обзор социально-нормативной семантики в лексическом поле «Труд».

В данной идеографической области присутствуют и понятия нормы, меры, эталона, стандарта, а значит, и идея отклонения от нормы, то есть аномалии: норма выработки, норма трудолюбия, мера ответственности, норма 
трудовых отношений в коллективе, субординация и ее нарушение, понятие профессионализма и непрофессионализма и т. д. И производственный стандарт, и нормы коммуникации, и нравственные императивы в сфере выполнения какой-либо работы детерминированы обществом, однако норма не всегда является социальной. Например, у человека может быть собственная, вне общественных ожиданий и стандартов, мера усталости от работы, работоспособность, индивидуальная предрасположенность к тому или иному виду деятельности и т. д. Между тем, например, работоспособность, будучи характеристикой индивидуальной, находится в фокусе наблюдений и оценок сторонних людей, поскольку приносит обладателю этого качества добрую славу, что немаловажно, например, для построения брачного союза, и обычно характеризует хорошего хозяина. Значит, это личное качество интегрируется в область социального, имеет значение для хозяйственных, семейных отношений, отражается на мнении микросоциума о человеке. Другой пример: мы ранее уже обращали внимание на то, что носитель диалекта противопоставляет работу интеллектуальным занятиям, ср. диал. Он и делать ничего не умеет - разве умственно что писать сможет (СРНГ, 27: 46). В то время как в жаргоне, просторечии и литературном языке присутствует представление о производительности интеллектуального труда и его сложности, в диалекте ум репрезентирован как сообразительность, деловитость, проворность, но только не как способность творить, созидать, производить нематериальный продукт (Leontyeva, 2008: 99-100). В этом случае отношение к интеллектуальному труду усвоено человеком из его социального окружения.

Если вести поиск «социальных смыслов» в номинациях лексикосемантического поля «Труд», то можно говорить о том, что в одних случаях социально-нормативная семантика включена в денотацию слов, в других присутствует в виде прагматических коннотаций.

\section{Социально-нормативные смыслы в денотации слов}

К числу идеограмм, отражающих социально-нормативную семантику в лексике труда, можно отнести, в частности, следующие: 'объединение людей для совместной работы', 'коллективная взаимопомощь', 'общественное порицание плохого или отстающего работника', 'работа на общественных началах', 'субординация' и т. д. Они принадлежат одновременно нескольким лексико-семантическим полям, одно из которых - «Труд», в качестве другого может выступать поле «Социальные взаимодействия» или другое по масштабу, принципам отбора лексики, но тематически сходное - соотносимое с обществом - поле («Социум», «Социальные отношения», «Социальная регуляция») и др.

Вкратце охарактеризуем вербальные репрезентации нескольких таких пограничных идеограмм, соотносимых со своеобычными для крестьянской среды формами трудовых взаимодействий между членами общины.

1) Коллективная помощь одному из членов общины, которая была нормой трудовой жизни в разных культурах, в том числе у старообрядцев Урало-Поволжья, татар, адыгов, карачаевцев, балкарцев, марийцев, чувашей и т. д. (Babashkin, 2011; Gimbatova, 2007; Gromyko, 1991: 41-50; Semenov, 1976; Scott, 1992 и мн. др.), является способом организации хозяйственной деятельности крестьян в русской деревне. Если в словарях современного русского языка слово помочи маркируется как устаревшее и областное (ССРЛЯ, 10: 1205), то в русских народных говорах бытуют десятки обозначений этого вида коллективной работы: перм. по́мочь 'собрание людей для оказания кому-либо помощи в работе, с угощением со стороны хозяев’ (Печь-ту били, дак Мария помочь ладила. Пиво про их варила. У Лиды помочь была: в один день 
все дрова испилили; Ходили друг кдругу на помочь: жали, косили. Работали бесплатно, за угощение) (СПГ, 2: 164), яросл., пск., твер. прихва́тка и яросл. прихва́точка 'коллективная помощь, помощь в работе' (СРНГ, 32: 48), перм. вечёрка 'коллективная работа в помощь кому-либо при трепке льна, производимая вечерами' (СРНГ, 4: 214), свердл. подёнщина 'коллективная помощь, помочи' (ЭИС, III: 171), орл. идти́ в камыши́, быть в камыша́х 'участвовать в помочах (коллективной крестьянской работе)' (СРНГ, 13: 33) и мн. др. Особой срочности могут требовать крестьянские работы, которые нужно закончить, например, в погожие дни, до начала дождей, чтобы убранное сено или зерно долго хранилось, поэтому в отдельных номинациях актуализирован этап завершения работы: волог. домоло́тки 'коллективная помощь по окончании молотьбы' (Чужие кто приходили молотить - большие домолотки бывали) (СГРС, 3: 250), волог. дожи́нки 'коллективная помощь во время жатвы' (Опять приглашали, на дожинки сходила) (Там же: 237), арх. бородно́ ‘коллективная помощь во время жатвы' (Там же: 111), ср. описание обрядового завивания бороды, завершавшего страду: «Борода - окончательная, при содействии помочи, уборка хлеба или сена. <..> Обыкновенно во второй половине или в конце августа (а для сена ранее) зажиточнейшие крестьяне заколачивают девушек, жонок и парней на бо́роду, т. е. просят дожать общими силами в один день остающийся на поле хлеб или убрать на пожне сено» (Там же: 109).

Кроме того, в русских говорах функционируют лексические единицы, называющие угощение работников по окончании помочей: пск., твер. нако́рмлины 'стол у хозяина, которому оказывается коллективная помощь в работе' (СРНГ, 19: 341), том. отпо́й и отпо́йка 'угощение вином за помощь в работе' (СРНГ, 24: 274) и др. Название блюда, которым хозяева расплачивались с работниками, зафиксировано во внутренней форме волог. пиро́жница 'одна из разновидностей коллективной помощи в деревенских работах' (Сосед пригласит на пирожнииу помочь) (СРГК, 4: 516), волог. назёмные пироги́ 'пироги, предназначенные для тех, кто вывозит навоз во время коллективной возки' (СРНГ, 19: 282), ср. об отжи́нной ка́ше: «В Онежском, Холмогорском и Пинежском уездах каша составляет главное угощение на празднествах по случаю окончания жатвы, особенно если дело не обходится без помочи; поэтому говорят например: Севодни у дяды Власа каша, т. е. звали на помочь, а потом будут угощать кашей» (Podvysockii, 1885: 64) и др.

Очевидно, что угощение участников помочи нельзя считать оплатой, поскольку она «не соразмерна» работе, хотя может быть неподъемной для некоторых членов крестьянской общины, ср. контекст к перм. почесýха (Раньше потрепухи, почесухи, помочи делали, а мы бедно жили, дак позовушки-то не ладили) (СРНГ, 31: 8).

Празднование окончания коллективной работы и сама работа составляют важную часть жизни крестьянской общины, предоставляя «сцену» для взаимодействий между людьми, участвующим в помочах. Для них есть специальные обозначения: свердл. помоча́не 'участники коллективной помощи' (ЭИС, III: 172), арх. захребе́тник 'тот, кто оказывал помощь в сельхозработах; за это его угощали' (СГРС , 4: 233), свердл. замоло́ченный 'человек, которому помогали молотить и обязанный отработать помочи по молотьбе’ (ЭИС, III: 173) и др.

Если взглянуть на помочь как часть стройной системы взаимопомощи, то становится ясно, что она вписана в прагматический контекст традиционной народной культуры. Коллективная взаимопомощь была формой организации хозяйственной жизни деревенского сообщества, необходимой для выживания крестьянства: «Помочи являлись одним из условий успешного 21 
функционирования индивидуального крестьяского хозяйства: они способствовали соблюдению крестьянами установленного графика сезонных работ (“круговые помочи”) при обмолоте зерна, засолке капусты и т. д., позволяли справиться с особо трудоемкой работой (заготовкой леса, строительством домов, печей и т. д.)» (Afanas'eva-Medvedeva, 2010: 298). Прагматичный настрой народного менталитета заключается в «обменном» характере помощи, который компенсирует условие бесплатности работы. Человек в числе прочих помогает соседу или любому другому жителю деревни, а тот позднее возвращает «долг» также участием в помочах. При этом работник не ставит никаких условий, а хозяин не дает обещаний участвовать в помощи семье каждого работника. Устойчивость такой системы проявляется в том, что ни отъезд одной семьи, ни смерть человека не может нарушить такую систему. «Ответное» участие в таких помочах - исполнение долга не перед конкретным человеком, помогшим когда-то, а перед самим крестьянским сообществом одной деревни. При всем том, что отсутствуют принуждение, контроль, условия, договор, такая форма взаимопомощи представляет собой «эффективную стратегию», обеспечивающую выживание в трудных обстоятельствах.

Совместная работа и коллективное празднование с угощением становятся площадкой для взаимных наблюдений, сравнений, оценок. Присутствующие замечают и оценивают умения и особенности поведения друг друга. Отстающие, как показывают их уничижительные обозначения и записи диалектной речи, подвергаются насмешкам: пск. поскреби́ша 'человек, который во время коллективной работы (помочей) опаздывает к обеду и, терпя насмешки, довольствуется остатками, поскребками' (СРНГ, 30: 171), смол. телёпа 'о последнем вознице с навозом, над которым шутят, подсмеиваются' (СРНГ, 43: 349) и др. Не одобряется и поведение тех, кто присоединился к работе позднее остальных, чтобы меньше работать, но угоститься вместе со всеми (перм. подхва́тка 'помощь кому-либо в окончании, завершении работы' (Жали с помочами; люди-те придут с утра все, а иные - с обеда, на подхватку, на пиво токо заробить) (СПГ, 2: 133)), а также тех, кто пришел к угощению, хоть и не участвовал в помочах (часто это - родные помочан - дети, жены): перм. нахребе́тник 'человек, который сам не принимал участия в общей работе (помочи), но пришел на угощенье на правах члена семьи одного из участников помочи' (Мужик-от ходил на помочь, а жена-то нахребетником явилась) (СРНГ, 20: 272), арх., перм., костром. захребе́тничать 'быть захребетником, получать угощение, не участвуя в помочах’ (Уж этот мужичок боговый! Сам робить на помочи не ходит, а все захребетничает) (СРНГ, 11: 163), волог., костром., перм., челяб., оренб. захребе́тник 'человек, пришедший на угощение вместо лица, принимавшего участие в помочах’ (Там же: 162), арх. захребе́тник 'человек, не принимавший участия в общественных работах, но пришедший на праздник в честь их завершения’ (СГРС, 4: 233), свердл. захребе́тники 'родственники, не участвующие в коллективной помощи, но приходившие на угощение' (ЭИС, III: 172) и др. Таким образом, лексическими средствами маркированы категории «отстающие в работе», «пришедшие на помочи позднее других», «не работавшие на помочах участники угощения». От развития соседских отношений на помочах как «арене» общественной жизни зависело распределение социальных ролей в замкнутом крестьянском социуме русской деревни.

Мотивационный анализ бытующих в русских народных говорах обозначений помочи (Leontyeva, 2011) помогает воссоздать представления об этом исчезнувшем феномене в тех его чертах, которые релевантны для языкового сознания носителя крестьянской культуры, во многом утраченной на 
сегодняшний день. Внутренняя форма слов хранит основные смыслы, составляющие понятие, подчеркивая назначение этого явления крестьянского быта (спомочь, пособка), его содержание (дроворубка, пожатуха, печебитье и др.), инициирование (званки, позовушка), способ организации (сгонщина, складиы, мирщина), системность организации, основанную на взаимности (заемно, отмолот, зажинать за беседы). Часть выявляемых моделей номинации реализует собственно социорегулятивные мотивы.

2) Рабочие артели. Идеограмма 'объединение людей для совместной работы с целью извлечения прибыли или облегчения тяжелого физического труда' воплощается в обозначениях артелей и действий, направленных на образование таких артелей: южн., кубан., яросл. спряга́ться с кем-либо 'объединяться для совместной обработки земли' (Половина жителей, имея по одной, по две пары быков, при пахоте спрягаются двора по два-три) (СРНГ, 40: 278), ленингр. спайться 'объединиться для совместной работы' (СРНГ, 40: 107), урал. сла́живаться 'объединяться для совместной работы' (СРНГ, 38: 227), том. сплести́сь 'объединиться для совместной работы' (Несколько семей сплетутся) (СРНГ, 40: 161), ряз. слепи́ться 'объединиться' (Да мы на покос слепились свой) (СРНГ, 38: 264), вят., перм., яросл. сва́живаться 'объединяться (о крестьянах) для совместного вывоза чего-либо, для летних работ' (Надо с соседом сваживаться навоз возить) (СРНГ, 36: 203), урал. совмеща́ться 'объединяться, соединяться для совместной рыбной ловли' (СРНГ, 39: 190), том. cocnápumb(ся) 'соединить(ся) в пару для совместной работы' (СРНГ, 40: 57), яросл., урал. свя́зка 'небольшая артель рыбаков, ведущих совместный лов рыбы (СРНГ, 36: 334), беломор. склады́ня 'рыболовная артель на паях, которые определяются по количеству орудий лова и рабочей силы' (СРНГ, 38: 22), печор. за́говор 'группа людей, договорившихся работать совместно, на паях' (Двациеть пять целовек в заговоре было, по три невода, по четыре) (СРГНП, 1: 228) и др. Артельные работы, объединения для выполнения тяжелой работы не предполагают помощи кому-либо одному, но тоже предназначены для взаимного облегчения тяжелого физического труда.

3) Последний в работе получает множество наименований в русских диалектах, и соответствующая идеограмма также характеризуется «встроенной» социальной семантикой, так как последний может быть определен только в «социальном соревновании» - во взаимодействии людей, ср. новосиб. перека́шивать 'обогнать, обойти кого-либо в косьбе' (СРНГ, 26: 120), омск. заброса́mь снопа́ми 'сноровисто, быстро работать' (Я бы сейчас всех забросала снопами, если б со мной взялись тягаться) (СРНГ, 39: 122). Ранее уже говорилось о последних (то есть позднее других заканчивающих работу) в коллективных помочах, но площадкой для сравнения трудовых навыков, умений, хозяйственности могут быть и другие виды работ.

Так, например, речь может идти не о совместной, коллективной работе людей, а об одновременности сезонных работ. Если своевременность начала и дружность окончания сезонных работ нарушается кем-либо из жителей деревни, он терпит насмешки и получает обидные наименования: иркут. лени́вая соха́ 'запоздалый выезд на весеннюю пахоту' (СРГС, 4: 396), новг. тащйть кили́ 'выполнять какое-л. трудное дело, работу и т. п.' (Все уже выкопали (картошку), а нам тащчить килу) (СРНГ, 43: 318), помор. кила́ 'символ срамоты' (Тому, кто последним убирал урожай (их называли «килова́на»), соседи вешали на забор или в сенях «килу́», сделанную из снопа скрученной соломы)' (Moseev, 2005: 68) и др.

Обозначения отстающих, как правило, универсальны для любых ситуаций совместной работы - для коллективной помощи, работы в артели, а также хозяйственных работ, выполняемых семьей (показателен контекст: Мати меня перегонит, скажет: «Я тебя на бороде оставила!»): карел. 
после́дний хвост 'о приехавшем последним' (СРГК, 5: 92), сиб. ки́ла 'о человеке, отставшем от других в косьбе, жатве' (СРНГ, 13: 206), петерб. ки́ла 'прозвище возчика навоза в поле, который отстает от других в работе' (Там же), пск. килу́н 'шуточное прозвище мальчика, который во время толоки везет в поле последний воз навоза' (Там же: 209), ср. петерб. подки́лок 'тот, кто явился с работы (домой) вслед за килой (отстающим от других в работе)' (СРНГ, 28: 31), перм. килово́з 'тот, кто едет в последней повозке обоза' (После всех Василко едет опять, все время он киловоз - дольше спит да дольше запрягает) (СПГ, 1: 388), свердл. килу́н 'приехавший с навозом последним' (ЭИС, III: 174) и др.

Отстающего или неумелого работника порицают вручением ему «позорящего» символа. Знаком насмешки служат разные предметы, называемые обычно килой: пучок сена или сжатого жита, прикрепленный к палке, петелька из ниточки и др. Знак, указывающий на огрех, иконичен: борода или пучок сена «изображают» траву на месте непрокоса. Реализуется сигнальная функция: палка служит позорящей меткой. Кила может заключать в себе фаллическую символику, ср. демонстрацию гениталий в целях оскорбления, унижения. Вручение килы или обещание ее установить на полосе отстающего сродни наказанию - деструктивному магическому действию, ср. сажать, ставить, пускать килу 'по суеверным представлениям - вызывая действие сверхъестественных сил, насылать грыжу, опухоль и т. д.’.

Субститутом вещного знака может выступать осмеивающая речевая формула: онеж. на́ тебе́ кили́ 'слова, которые говорят тому, кто плохо работает, подавая при этом палку с привязанным на конце сеном’ (СРГК, 2: 345); «Ура! Ванькина кила, Сашкин подкилок, Хозяину в затылок! - [дразнилка для возчиков-детей: для тех, кто приехал с навозом последним и предпоследним]» (ЭИС, III: 174). В лексикографических источниках и лексических архивах хранятся записи формул обещания отстающему расправы: волог. привяза́mь $к$ ни́жней бороде́ 'угроза тому, кто плохо косит или жнет' (СГРС, 1: 157), арх., волог. за хохо́л пове́сить (привяза́mb) 'брань, адресованная человеку, оставляющему непрокосы - брак при косьбе' (Кто тут косил? Котору за хохол повесить? За хохол тебя надо привязать, наостовляет кто пупов сзади) (СГРС , 4: 232), костром. за хохо́л привяза́mь 'угроза тому, кто плохо косит, оставляя непрокошенные участки' (Тебя надо за это привязать, за этот хохол) (ЛК ТЭ), костр. привязать за трави́нки 'угроза тому, кто плохо косит' (Плохо косишь - привяжём тебя за эти травинки) (ЛК ТЭ), арх. за во́лосы нать привяза́mь 'слова, которые говорят человеку, который косит с огрехами, оставляет нескошенными полоски травы' (СГРС, 4: 35), костром. за я́ŭųa привя́зывать 'угроза тому, кто плохо косит' (За яйца только привязывать!) (ЛК ТЭ) и др. Ритуальное высмеивание, несомненно, выполняет социальнонормативную функцию, поскольку является акцией демонстрации неодобрения и сообщением о существовании внутреннего общинного контроля.

\section{Социально-нормативные смыслы в оценочных характеристиках человека по трудовым качествам}

Как уже было сказано, социальная семантика представлена в лексике поля «Труд» на разных уровнях - не только в денотации языковых фактов, но и в виде коннотаций, обнаруживаемых на уровне контекстных смыслов. Так обстоит дело с оценочными характеристиками человека по его трудовым качествам. Лексическими и фразеологическими средствами русского языка, и в частности русских народных говоров, запечатлены представления о хорошем и негодном работнике. Анализ материала показывает, что в языке маркированы 
такие качества, как трудоспособность и немощность, умелость и неумелость, трудолюбие и лень, умение и неумение работать В коллективе. Все названные характеристики человека приобретают в народной культуре «социальный резонанс».

1) Трудоспособность и немоцность. Возраст и физическое здоровье служат естественными причинами годности или негодности к работе, на что указывает наличие в русских народных говорах цельнооформленных лексем, а также идиом, обозначающих трудоспособного либо немощного человека: том. рабо́чая рука́ 'работоспособный' (Тятя рабочая рука один был. Отец один работал) (СРГС, 4: 190), карел., мурман. живова́тый 'могущий, способный трудиться, выполнять какую-нибудь работу’ (Она [соседка] еще живовата, за водой ходит, поў вымоет; Я опять живовата стала, ну, здоровей стала, делать что могу по дому) (СРГК, 2: 55), олон. быть в степе́ни 'быть бодрым, крепким, трудоспособным' (СРНГ, 41: 140), иркут. нерабо́тный 'больной' (СРНГ, 21: 137), перм. броси́ха 'о человеке старом, дряхлом, не имеющем сил работать' (Старый стал, дык бросиха стал теперь; Калека... и работать не может, вот его считают бросихой) (АС, 1: 93), перм. безрабо́тица (собир.) 'люди, не принимающие участия в хозяйственно важных работах' (Сейчас у нас всё в деревне живут всё старики да инвалиды, всё безработица) (Там же: 60), ленингр. жив - не го́ден 'о нетрудоспособном человеке' (Oн в аварию попал, сразу не умер, да всё равно жив - не годен) (СРГК, 2: 56). Показательно лежащее в основе последней идиомы противопоставление «живости» и нетрудоспособности, свидетельствующее о том, что годность к работе видится носителю языка как атрибут живого, здорового человека, как одна из его функций.

Условное разграничение социума на центр (ядро) и периферию (окраины) - одна из характерных черт народного мировоззрения, нашедшая выражение во внутренней форме перм. сторо́нник 'о человеке, не способном к работе, инвалиде' (Заболел, его уж не стали принимать никуда: сторонник, не способныц уж к работе) (СРНГ, 41: 247). «Социальные окраины», к которым относят, в частности, не способных работать - детей, стариков, немощных обозначаются существительными с грамматическим значением собирательности: волог. лихора́mье 'о старых немощных людях' (В деревне остается одно лихоратье, нерабочие кости) (СРГК, 3: 132), волог. старьё да барье 'о неработающем человеке' (Старье да барье осталось) (СРНГ, 41: 90). Волог. nодреше́чве 'те, кто негоден к работе' (Теперь в деревне одно подрешечье осталось) (СРГК, 4: 666), возможно, связано с решето и выражает семантику бедности, нищеты, ср. карел. решети́стый 'дырявый, прохудившийся', карел. держа́ться на решете́ ‘кое-как сводить концы с концами' (СРГК, 5: 521).

2) Умелость и неумелость. Годность или негодность к работе связывается с умелостью, сообразительностью либо неумелостью и одним из ее проявлений - медлительностью. Так, расторопность, быстрота действий запечатлена в печор. всё в рука́х кружа́ется у кого 'о человеке, который быстро, умело работает' (Он дельный мужык, у него сё в руках кружаеция) (СРГНП, 1: 354), печор. крутя́щзий ‘очень быстро, проворно работающий’ (У нас Катя жыла, така крутяшиа была) (Там же: 356), курск., яросл. спорина́ 'умение, ловкость в труде, обеспечивающие достаток, прибыток, благополучие в доме' (Вот какая у Катерины спорина при вязании, всех обогнала. Нет спорины - говорят при медленной работе) (СРНГ, 40: 224).

Диалектные обозначения плохой работы, неумелого человека образуют самую многочисленную группу, приведем лишь несколько фактов: волж. решмак 'название бурлака, слабосильного и неумелого в работе, получающего самую низкую плату' (СРНГ, 35: 91), смол. мяку́ша 'женщина, 
непривычная к труду’ (Мякуша mы, у тябе с рук усё сыпициа) (ССГ, 6: 126), арх. из-под ле́вой руки́ 'такой, который не соответствует предъявляемым к нему требованиям, плохой' (Тот работник из-под левой руки) (СРГК, 3: 103), мурман. кýpna 'тот, кто делает все не так, плохо' (Там же: 70), карел., арх. недопёха 'неумелый, нерасторопный, несообразительный в работе человек' (Там же: 404) и др. Качество прядения представлено в лексике при помощи шкалы, отражающей толщину получаемой нити: «тонкий - средний - толстый», ср. арх. среднепря́ха 'о женщине, которая обычно прядет ни хорошо, ни плохо' (Она хорошо прядет - тонкопряха, скажет, бывает толстопряха, среднепряха) (СРНГ, 40: 308). Однокоренным с негодный является перм. безго́дина 'неумелый, неспособный что-л. делать человек; неумеха' (Oн косить-то не мог, дак безгодиной звали) (СПГ, 1:30). Рамки статьи не позволяют показать все многообразие этой лексики, однако получить о ней представление можно, обратившись к работе М. А. Ереминой (2003).

Трудовые навыки получают оценку в категориях социальной перспективы, это обычно фиксируют контексты: ср.-урал. тихобзя́инка 'человек, который делает все медленно, плохо работает' (Ак, тихобзяинка, че тихо робишь? Как замуж пойдешь?) (СРНГ, 44: 143), перм. беспу́тка 'девушка, женщина, ничего не умеющая делать' (За беспуток-то мало кто сватался, кому жена неумеха нужна) (СПГ, 1: 37), олон., арх., свердл. станли́вый 'рано встающий; работящий, трудолюбивый' (Попрекать станут твоего мужа богоданного, что ленивая у него взята, не станливая) (СРНГ, 41: 50), арх. незауме́льий 'нехозяйственный' (Он мужик незаумелый, все деньги пропивал, по хозяйству ничего не умел, вот жена от него и ушла) (СРНГ, 21:48) и др. Наблюдая за тем, как человек работает, окружающие оценивают его с позиций некоторой нормы: «Воспроизводимый во множестве актов деятельности способ выполнения работы (быстро, ловко, умело, с увлечением ит. п.), ведущий к положительному результату, становится трудовой нормой, на которую в дальнейшем ориентируется носитель языка при положительной оценке трудового процесса и деловых качеств человека» (Еремина, 2003: 228). Итак, в народной культуре умение работать не является исключительно личностным качеством, оно приобретает социальное звучание, поскольку ему придается большое значение, например, при выборе невесты, жениха.

3) Трудолюбие и тунеядство. Желание и нежелание человека трудиться - психологические характеристики личности - также переосмыслены в их взаимосвязи с предметно-бытовой и социальной сферами. У работящего крепкое хозяйство, у нерадивого - запущенный дом: сарат. спра́вный в рабо́те 'ответственный, исправный, трудолюбивый' (Шабёр [сосед] справный во всякой работе) (СРНГ, 40: 259), костром., калин., пенз. неделу́ха и недёлуха 'лентяйка, бездельница' (Иван, у тебя хозяка-та неделуха; Да она недёлуха, дома у них сроду грязь) (СРНГ, 21:11), свердл. нетка́шиха-непря́шиха 'лентяйка, белоручка' (Невеста-то неткашиха-непряшиха, одно слово - лентяйка) (Там же, с. 135). Запущенная изба бездельника и обихоженный рачительным хозяином-трудолюбцем дом - предмет оценок, обсуждений, сплетен, а от этих оценок зависит построение связей внутри крестьянской общины.

О двух аспектах осмысления лени пишет М. А. Еремина, выявившая на основе анализа лексического материала две оценочные позиции: утилитарную и этическую (Еремина, 2003: 52). С одной стороны, бездельник воспринимается с позиции утилитарной нормы: человеку дается квалификация с точки зрения «практической пригодности / непригодности», диагностируемой как раз по хозяйственности / бесхозяйственности. С другой стороны, оценка лентяя 
отталкивается от представлений о социальных нормах: безделье «неэтично» по своей сути, поскольку лентяй живет за счет окружающих.

Анализ лексического материала побуждает исследователей заключить, что «социальной нормой признается не безразличное, нейтральное, а именно положительное, добросовестное отношение к труду, отклонения от нее оцениваются негативно и осуждаются обществом» (Lukyanova, 1985: 59).

При наличии такой установки любопытно, что в сознании носителей языка чрезмерная увлеченность человека работой также может восприниматься как нарушение нормы: «Особым моментом в квалификации стало внимание к особенностям поведения человека в процессе труда, эксплицируемое мотивационной моделью 'хорошо работать' $\leftarrow$ 'выходить за рамки приличного поведения'. В данном случае языковое сознание констатирует несоответствие поведения общепринятой норме и сопровождает номинацию неодобрительной оценкой» (Eremina, 2003: 71).

4) Умение и неумение работать в коллективе. Традицией общинного выполнения некоторых хозяйственных работ, обычно связанных с тяжелым физическим трудом, обусловлено внимание носителя народной культуры к коммуникативным характеристикам личности, умению согласовывать действия внутри трудовой группы: арх. срабо́тка 'согласованность в работе, сработанность' (Сработки нет между ними, друг друга устофиливают, ругают) (СРНГ, 40: 301). Среди обозначений членов артели особенно много слов, называющих людей, которые не хотят или не могут должным образом выполнить свою часть работы в согласии с другими: бурят. само́шник 'индивидуалист, человек, противопоставляющий себя обществу, коллективу' (С самошником дела не сладишь... Так самошника мы потом из артели выгнали) (СРГС, 4: 226), бурят., читин. чи́za 'человек, не желающий подчиняться заведенному порядку' (Чига то и дело уходил неизвестно куда из артели. А когда чига приходил, его спрашивали, где был, чига отвечал, что это только дело его. Пришлось чигу из артели прогнать) (СРГС , 5: 291). Плохой работник подводит остальных: забайкал. саботе́льник 'человек, намеренно срывающий какую-либо работу или умышленно плохо ее исполняющий’ (Кто в артели из саботельников соберется, то беда) (СРНГ, 36: 13), моск. прорь́вочник (женск. прорьівочница) 'тот, кто не выполняет план, допускает прорыв в работе' (СРНГ, 32: 221), бурят. утя́ 'человек, переходящий с работы на работу' (На утяга какая надёжа. Утяг сёдне здеся, а завтра тама) (СРГС, 5: 178), ср. костром. сма́зывать работу 'портить, сводить на нет работу, дело' (Товарищ всю нашу работу смазал) (СРНГ, 38: 339). Отношение к плохим работникам, выражающееся в желании избавиться от них, запечатлено в иллюстративном контексте к карел. ло́ктем глаза́ перекрести́mь 'выразить большую радость, удовлетворение по поводу чего-н.' (Вот мне добраться до того места, так локтем глаза бы перекрестила; а можно к плохому сказать: вот уходит с бригады плохой работник, так все локтем глаза перекрестят) (СРГК, 4: 451).

Как можно видеть, в наивно-языковой картине мира негодность к работе является характеристикой не столько личностной, сколько социальной. На основании анализа лексики русских народных говоров выявляется несколько ипостасей негодности к работе, значимых для носителей народной и прежде всего крестьянской культуры: неработоспособность в силу объективных причин - возраста, болезни (немощность); недостаток мастерства и опыта (неумелость); нежелание работать (тунеядство, лень); неспособность и нежелание работать согласии с коллективом. Они репрезентируются в лексическом диалектном материале как факторы, формирующие структуру общества, его расслоение, разделение крепких хозяйственников и маргинальных слоев населения, а также 
как факторы, определяющие «социальные перспективы» человека, его участие во взаимодействиях людей внутри общины - в заключении брачных союзов, объединении для общинных работ, создании ремесленнических артелей.

\section{Выводы}

Итак, лексика труда включает не только названия материалов, инструментов, способов, приемов, этапов, продуктов деятельности, результативности выполнения работы, но и слова, запечатлевшие социальную природу коллективного труда (консолидацию усилий членов общины, установившуюся в естественных бытовых условиях взаимность и очередность участия в работе, потребность в определенной форме трудовых взаимодействий той социальной среды, в которой она сформировалась как явление и т. д.) или социальный аспект оценочных характеристик человека по способности работать и отношению к труду. Социально-нормативные смыслы могут, таким образом, концентрироваться в отдельных сегментах лексико-семантического поля, которое имеет своим ядром иную, не социальную, семантику и лишь в какой-то своей части пересекается с лексикой, описывающей общественные отношения.

\section{References}

AFANAS'EVA-MEDVEDEVA, G. V. 2010. Harakter reprezentacii tradicionnoi verbal'noi kul'tury $\mathrm{v}$ «Slovare govorov russkih starozhilov Baikal'skoi Sibiri». In: Vestnik Buryatskogo gosudarstvennogo universiteta, n. 10, pp. 293-299. ISSN 1994-0866

BABASHKIN, V. V. 2011. Koncepciya «moral'noi ekonomiki» krest'yanstva i rossiiskaya derevnya nachala XX veka. In: Krest'yanovedenie. Teoriya. Istoriya. Sovremennost': uchenye zapiski, n. 6, pp. 135-156. ISBN 978-5-7749-0673-4

BORSHEVA, O. V. 2012. Konceptual'noe pole «Trud» skvoz' prizmu idiomatiki (na materiale russkogo i angliiskogo yazykov): dissertaciya...kandidata filologicheskih nauk. Saratov. 303 p.

BRYSINA, E. V. 2001. Trudovaya deyatel'nost' cheloveka i ee otrazhenie v donskoi dialektnoi frazeologii In: Sel'skaya Rossiya: proshloe i nastoyashee: doklady i soobsheniya 8-i ros. nauch.-prakt. Konf. n. 2. Moskva: Enciklopediya rossiiskih dereven', pp. 200-202. ISBN 5-88367-056-3

GIMBATOVA, M. B. 2007. Kommunikativnye formy povedeniya nogaicev v obychae vzaimopomoshi «sha'vsheke». In: Izuchenie kul'turnogo naslediya narodov Rossii aktual'naya zadacha: materialy Vserossiiskoi nauchno-teoreticheskoi konferencii. Mahachkala: Epoha, pp. 146-150.

GROMYKO, M. M. 1991. Mir russkoi derevni. Moskva: Molodaya gvardiya, 270 p. ISBN 5-235-01030-2

EREMINA, M. A. 2003. Leksiko-semanticheskoe pole «Otnoshenie cheloveka k trudu» V russkih narodnyh govorah: etnolingvisticheskii aspekt: dissertaciya ... kandidata filologicheskih nauk. Ekaterinburg. 253 p.

KRUGLIKOVA, L. E. 1992. Leksiko-frazeologicheskaya paradigma «chelovek, polozhitel'no otnosyashiisya $\mathrm{k}$ trudu» $\mathrm{v}$ russkih narodnyh govorah. In: Leksicheskii atlas russkih narodnyh govorov (Mat-ly i issledovaniya). Sankt-Peterburg., pp. 83-92.

LEONTYEVA, T. V. 2008. Intellekt cheloveka v russkoi yazykovoi kartine mira: monografiya; pod red. E. L. Berezovich. Ekaterinburg: Izd-vo GOU VPO «Ros. gos. prof.-ped. un-t». 280 p. ISBN 978-5-8050-0303-6

LEONTYEVA, T. V. 2011. Nazvaniya kollektivnoi pomoshi sosedyam v russkoi derevne: motivacionnyi analiz. In: Vestnik Krasnoyarskogo gosudarstvennogo pedagogicheskogo universiteta im. V. P. Astaf'eva, t. 2, n. 3, pp. 82-88. ISSN 19950861 
LITVINOVA, T. A. 2011. Leksemy, harakterizuyushie cheloveka po otnosheniyu k trudu, v voronezhskih govorah. In:: Vestnik Chelyabinskogo gosudarstvennogo universiteta, n. 10, pp. 73-76. ISSN 1994-2796

LUKYANOVA, N. A. 1985. Leksiko-semanticheskaya gruppa «chelovek lenivyi» v dialektnoi sisteme: opyt semanticheskogo analiza. In:: Russkaya leksika v istoricheskom i sinhronnom osveshenii: sbornik statei. Novosibirsk: Nauka. Sib. otdnie, pp. 58-79.

MARKELOVA, E. V. 2004. Kognitivno-semanticheskaya struktura imen deyatel'nosti (na materiale russkih poslovic o trude i leni) : dissertaciya... kandidata filologicheskih nauk. Novosibirsk. 237 p.

MOSEEV, I. I. 2005. Pomor'ska govorya: kratkii slovar' pomorskogo yazyka. Arhangel'sk. ISBN 5-7619-0243-5

SEMENOV, Yu. I. 1976. Pervobytnaya kommuna i sosedskaya krest'yanskaya obshina. In: Stanovlenie klassov i gosudarstv. Moskva: Nauka, pp. 25-37.

PODVYSOCKII, A. I. 1885. Slovar' oblastnogo arhangel'skogo narechiya v ego bytovom i etnograficheskom primenenii. Sankt-Peterburg: Tipografiya Imperatorskoi Akademii Nauk. 198 p.

SCOTT, J. 1992. Moral'naya ekonomika krest'yanstva kak etika vyzhivaniya. In: Velikii neznakomec: krest'yane i fermery v sovremennom mire : hrestomatiya: per. s angl. Moskva : Progress, pp. 202-210. ISBN 5-01-003016-0

SUSLOVICH, S. V. 2010. Reprezentaciya koncepta trud v sovremennyh aforizmah o trude. In: Voprosy kognitivnoi lingvistiki, n. 4, pp. 79-82. ISSN 1812-3228

TOKAREV, G. V. 2003. Teoreticheskie problemy verbalizacii koncepta «Trud» v russkom yazyke : dissertaciya...doktora filologicheskih nauk. Volgograd. $472 \mathrm{p}$.

YANYSHKOVA, I. 2008. O nazvaniyah besplatnoi pomoshi sosedyam v cheshskom yazyke In: Etnolingvistichka prouchavaœa srpskog i drugih slovenskih jezika: u chast akademika Svetlane Tolstoj. Beograd: SANU, Odelenie jezika i knizhevnosti, pp. 433-439. ISBN 9788670254756

\section{Material resources:}

AC - Slovar' govora d. Akchim Krasnovisherskogo raiona Permskoi oblasti (Akchimskii slovar'). 1984-2011. Perm', n. 1-6.

ЛК ТЭ - Leksicheskaya kartoteka toponimicheskoi ekspedicii (hranitsya na kafedre russkogo yazyka i obshego yazykoznaniya Ural'skogo gosudarstvennogo universiteta im. A. M. Gor'kogo, nyne $\square$ Ural'skogo federal'nogo universiteta imeni pervogo Prezidenta Rossii B. N. El'cina).

СГРС - Slovar' govorov Russkogo Severa. 2001-2009. Ekaterinburg: Izd-vo Ural'skogo un-ta, t. 1-4.

СПГ - Slovar' permskih govorov. 2000-2002. Perm': Knizhnyi mir, n. 1-2.

СРГК - Slovar' russkih govorov Karelii i sopredel'nyh oblastei. 1994-2005. SanktPeterburg: Izd-vo Sankt-Peterburgskogo un-ta, n. 1-6.

СРГНП - Slovar' russkih govorov Nizovoi Pechory. 2003-2005. Sankt-Peterburg: Filologicheskii fakul'tet SPbGU, t. 1-2.

СРГС - Slovar' russkih govorov Sibiri. 1999-2006. Novosibirsk: Nauka. Sib. predpriyatie RAN, t. 1-5.

СРНГ - Slovar' russkih narodnyh govorov. 1965-2011. Moskva; Leningrad; SanktPeterburg: Nauka, vyp. 1-44.

ССГ - Slovar' smolenskih govorov. 1974-2005. Smolensk, t. 1-11.

ССРЛЯ - Slovar' sovremennogo russkogo literaturnogo yazyka. 1948-1965. Moskva:

Nauka; Leningrad: Izdatel'stvo AN SSR, t. 1-17.

ЭИС - VOSTRIKOV, О. V. 2000. Tradicionnaya kul'tura Urala: etnoideograficheskii slovar' russkih govorov Sverdlovskoi oblasti. Ekaterinburg, n. 1-5. 


\section{Сокращения}

арх. - архангельское

беломор. - беломорское

бурят. - бурятское

волж. - волжское

волог. - вологодское

вят. - вятское ${ }^{1}$

диал. - диалектное

забайкал. - забайкальское

иркут. - иркутское

калин. - калининское ${ }^{2}$

карел. - карельское

костром. - костромское

кубан. - кубанское

курск. - курское

ленингр. - ленинградское

моск. - московское

мурман. - мурманское

новг. - новгородское

новосиб. - новосибирское

олон. - олонецкое ${ }^{1}$

омск. - омское

онеж. - онежское оренб. - оренбургское

орл. - орловское

пенз. - пензенское

перм. - пермское

петерб. - петербургское

печор. - печорское 2

помор. - записанное в Поморье

пск. - псковское

ряз. - рязанское

сарат. - саратовское

свердл. - свердловское

сиб. - сибирское

смол. - смоленское

ср.-урал. - среднеуральское

твер. - тверское

том. - томское

урал. - уральское

челяб. - челябинское

читин. - читинское

южн. - южное ${ }^{2}$

яросл. - ярославское

Words: 5013

Characters: 38158 (21,20 standard pages)

Tatyana V. Leontyeva, PhD.

Russian State Vocational Pedagogical University

Mashinostroitelej 11

620098 Yekaterinburg

Russia

leotany@mail.ru

${ }^{1}$ Вятская губерния - административноя единица Российской империи, СССР (ныне на этих территориях располагаются части Кировской области, Удмуртии); Олонецкая губерния - административная единица Российской Империи с центром в г. Петрозаводске.

${ }^{2}$ Калин. - записанное на территории г. Калинина, существовавшего в 19311990 годах; впоследствии - Тверь; печор. - записанное по реке Печоре; южн. зафиксированное на территориях, находящихся к югу от Москвы 